\title{
Can COVID-19 be an airborne infection?
}

\section{CS Edirisuriya $^{1}$, Madhurangi Perera ${ }^{2 *}$, Nilanthi Suraweera ${ }^{1}$, Nadeeka Chandraratne ${ }^{3}$, Chathurani Mekala Wickramaarachchi ${ }^{4}$}

${ }^{1}$ National Institute of Health Sciences, Kalutara, Sri Lanka; ${ }^{2}$ Family Health Bureau, Ministry of Health; ${ }^{3}$ Office of the DDG PHSII, Ministry of Health, Sri Lanka; ${ }^{4}$ National Program for Tuberculosis Control and Chest Diseases, Ministry of Health, Sri Lanka

Correspondence: madhurangiep@gmail.com iDhttps://orcid.org/0000-0002-6916-9010

DOI: https://doi.org/10.4038/jccpsl.v26i5.8362

Received on 22 May 2020

Accepted on 24 May 2020

\section{Highlights}

- COVID-19 is transmitted via infected respiratory droplets that could remain suspended in air after being produced.

- Viral particles have been isolated in droplet nuclei. In addition, the evidence on pre-symptomatic and asymptomatic transmission grows.

- The uncertainty of COVID-19 transmission may hinder the measures on disease prevention.

\section{Introduction}

COVID-19 has been classified as a respiratory tract infection. Its inter-human transmission occurs as a contact and droplet infection (1).

Droplets of the human respiratory tract are produced while breathing, speaking, coughing, sneezing, etc (2). The size and amount of the droplets produced vary according to the generation process (3). The widely accepted size of a droplet is more than $5 \mu \mathrm{m}$ (2, 4) and its main constituents are upper respiratory tract secretions and saliva. When an individual is infected with a respiratory tract infection, the droplets produced may contain the disease pathogen. These pathogen laden respiratory droplets are capable of transmitting the disease to a susceptible person. The respiratory droplets are usually deposited on surfaces within $1-2 \mathrm{~m}$ due to its relative heavy weight $(2,4)$. The respiratory droplets are able to remain suspended in air after exiting only if the droplet size is less than or equal to $5 \mu \mathrm{m}(2,4-5)$. Technically, these droplets are named as 'droplet nuclei 'and are capable of traveling relatively far from the source of origin (56). The distance travelled and the existence of droplet nuclei may be affected by many environmental factors such as, temperature, relative humidity, air velocity, etc. $(2,4)$. 


\section{What is an airborne infection?}

An airborne infection is a mechanism where disease pathogens are transmitted by particles, dust or droplet nuclei (less than or equal to $5 \mu \mathrm{m}$ ) suspended in the air (7-8). These air suspended particles can be produced by an infectious patient or a carrier. It is also possible to re-suspend an infective droplet as a droplet nucleus from its deposited surface (7) and in this instance, the droplet nuclei should contain viable pathogens in sufficient amounts to meet the minimum infective dose to cause infection $(2,7-8)$.

\section{Can COVID-19 be an airborne infection?}

Theoretically, COVID-19 can spread as an airborne infection $(3,9)$. In a laboratory experiment, viable SARS-CoV-2 was isolated in suspended air after 3 hours of generation. Since these droplet nuclei were generated artificially using machines in the laboratory, it can be argued that the generation process is incomparable with the generating mechanisms of human individuals, however this could represent the droplet generation taking place during medical procedures (10).

In another study conducted in a hospital isolation unit, researchers were able to isolate SARS-CoV-2 viral particles in air vents of the unit, but the viability of the virus could not be established (11). A similar study suggests SARS-CoV-2 virus can be airborne and has the potential to resuspend from personal protective equipment (PPE). In this study, viral viability was not studied (12). In contrast to this evidence, the observations made on approximately 75,000 COVID-19 patients in China were not suggestive of the possibility of airborne transmission (13).

\section{Public health importance}

Possible airborne transmission of COVID-19 may pose several challenges in disease control and preventive activities. First, it may render physical distancing less effective in disease prevention. Second, airborne virus can remain suspended in air for extended periods of time giving more opportunity to infect a susceptible. Third, smaller size of the air suspended droplet nuclei facilitates the virus to reach the site of infection more easily. Hence, COVID-19 disease control and prevention would be very difficult and may warrant stringent methods to be used for containment. This will lead to more socioeconomic consequences apart from health concerns.

Removal and disposal of used PPE may need more strict guidelines due to the growing evidence on the pre-symptomatic and asymptomatic status of the disease and the possibility of airborne COVID-19 transmission via re-suspension. This may lead to rigorous and more complex guidelines on PPE use and disposal, increasing the operational cost.

\section{Recommendations}

Currently, airborne transmission of COVID-19 cannot be completely ruled out. Hence, the public should be educated to be cautious on this uncertainty. It will be beneficial to include disease control and prevention methods to limit transmission via aerosols. Further evidence gathering and research are encouraged to improve the persisting knowledge gap on aerosol transmission of COVID-19 (13).

\section{Author Declaration}

Acknowledgements: We wish to express our deep gratitude to Dr Pushpa Jayawardana for her guidance in reading and reviewing the article.

Author contributions: All authors contributed in evidence gathering, tabulating the evidence, formulating the structure writing, reading and reviewing of the article.

\section{References}

1. World Health Organization. 2019 Novel Coronavirus (2019-nCoV): Strategic Preparedness and Response Plan, February 2020. World Health Organization. Available from: https: //www. who.int/ publicationsdetatrategic-prepare dness-and-response-plan-forthe-new-coronavirus. Accessed 4 April 2020.

2. Gralton J, Tovey E, McLaws ML, Rawlinson WD. The role of particle size in aerosolised pathogen 
transmission: a review. Journal of Infection 2011; 62(1): 1-13. DOI: 10.1016/j.jinf.2010.11.010.

3. Kutter JS, Spronken MI, Fraaij PL, Fouchier RA, Herfst S. Transmission routes of respiratory viruses among humans. Current Opinion in Virology 2018; 28: 142-51. DOI: 10.1016/j.coviro.2018.01.001.

4. Xie X, Li Y, Chwang ATY, Ho PL, Seto WH. How far droplets can move in indoor environments revisiting the Wells evaporation-falling curve. Indoor Air 2007; 17: 211-225. DOI: 10.1111/j.1600-0 668.2006.00469.x.

5. Atkinson J, Yves C, Otaiza F, Pessoa-Sliva CL. Natural ventilation for infection control in health-care settings. Geneva: World Health Organization 2009. Available from: https:// apps. who.int /iris/ bitstream/handle/ 10665/44167/9789241 547857_eng.pdf?seq.

6. International Epidemiological Association. A Dictionary of Epidemiology. 6th ed. Porta M Vol. 15, International Journal of Epidemiology. Oxford University Press, 2014 : 277 . Available from: http:// dx. doi. org/10.1093/ije/15.2.277.

7. Tellier R, Li Y, Cowling BJ, Tang JW. Recognition of aerosol transmission of infectious agents: A commentary. BMC Infectious Diseases 2019; 19: 101. DOI: 10. 1186/s12879-019-3707-y.

8. Cole EC, Cook CE. Characterization of infectious aerosols in health care facilities: An aid to effective engineering controls and preventive strategies. American Journal of Infection Control 1998; 26(4): 453-464. DOI:10.1016/s0196-6553(98) 70046-x.
9. Bourouiba L. Turbulent gas clouds and respiratory pathogen emissions: potential implications for reducing transmission of COVID-19. Journal of American Medical Association 2020; E1-E2. DOI: 10.1001 /jama.2020.4756.

10.Stoeldraijer L, Bonneux L, van Duin C, van Wissen L, Janssen F. The future of smoking-attributable mortality: the case of England \& Wales, Denmark and the Netherlands. Addiction 2015; 110(2): 336-345. DOI: 10.1111/add.12775.

11. Ong SWX, Tan YK, Chia PY, Lee TH, Ng OT, Wong MSY, et al. Air, surface environmental, and personal protective equipment contamination by severe acute respiratory syndrome coronavirus 2 (SARS-CoV-2) from a symptomatic patient. Journal of American Medical Association 2020; 323(16). DOI: 10.1001 /jama. 2020.3227.

12. Liu YY, Ning Z, Chen Y, Guo M, Liu YY, Gali NK, et al. Aerodynamic characteristics and rna concentration of SARS-CoV-2 aerosol in Wuhan hospitals during COVID-19 outbreak. bioRxiv 2020; 86(21): 2020.03.08.982637. DOI: 10. $1101 /$ 2020.03.08.982637.

13. World Health Organization. Modes of transmission of virus causing COVID-19: implications for IPC precaution recommen dations. WHO Scientific Brief, March 2020: 1-3. Available from: https: //www. who.int/ news-room/ commentaries /detail/ modesof-transmission-of-virus-causing-covid-19implications-for-ipc-precaution-recomm endations. 